\title{
Foreign executive appointments: a multilevel examination
}

Article

Accepted Version

Greve, P., Biemann, T. and Ruigrok, W. (2015) Foreign executive appointments: a multilevel examination. Journal of World Business, 50 (4). pp. 674-686. ISSN 1090-9516 doi: https://doi.org/10.1016/j.jwb.2014.10.012 Available at https://centaur.reading.ac.uk/37953/

It is advisable to refer to the publisher's version if you intend to cite from the work. See Guidance on citing.

To link to this article DOI: http://dx.doi.org/10.1016/j.jwb.2014.10.012

Publisher: Elsevier

All outputs in CentAUR are protected by Intellectual Property Rights law, including copyright law. Copyright and IPR is retained by the creators or other copyright holders. Terms and conditions for use of this material are defined in the End User Agreement.

\section{www.reading.ac.uk/centaur}

\section{CentAUR}

Central Archive at the University of Reading

Reading's research outputs online 


\author{
PEDER GREVE ${ }^{\text {a }}$ * \\ e-mail: peder.greve@henley.ac.uk \\ TORSTEN BIEMANN ${ }^{b}$ \\ e-mail: biemann@bwl.uni-mannheim.de \\ WINFRIED RUIGROK ${ }^{\mathrm{c}}$ \\ e-mail: winfried.ruigrok@unisg.ch
}

${ }^{a}$ Henley Business School, University of Reading

International Business and Strategy

Henley-on-Thames, Oxon, RG9 3AU, UK

Tel: (+44)-1491-414-522

Fax: (+44)-1491-571-574

${ }^{\mathrm{b}}$ University of Mannheim

Chair of Human Resource Management and Leadership

DE-68131 Mannheim, Germany

Tel: (+49)-621-181-1467

${ }^{\mathrm{c}}$ University of St. Gallen

Research Institute for International Management

Dufourstrasse 40a

CH-9000 St. Gallen, Switzerland

Tel: (+41)-71-224-2448

Fax: (+41)-71-224-2447

* Corresponding author

Accepted for publication in Journal of World Business. 


\title{
FOREIGN EXECUTIVE APPOINTMENTS: A MULTILEVEL EXAMINATION
}

\begin{abstract}
As multinational enterprises (MNE) expand, their attachment to the country of origin is challenged by the need to adapt to an increasingly diverse geographical posture. We examine how these countervailing forces affect top management team (TMT) composition and test a model that associates foreign executive appointments with individual- and firmlevel antecedents. Using multilevel data comprising 1,446 TMT appointments at 360 large European firms between 2001 and 2005, we show that individual experiential characteristics, the type of TMT function, prior performance of the MNE, and the MNE's overall degree of internationalization are associated with foreign TMT appointments. We discuss how our findings contribute to the international business literature and complement recent research on the internationalization of TMTs.
\end{abstract}

Key words: top management teams, cross-border mobility, executive appointments, internationalization, multilevel analysis. 


\section{INTRODUCTION}

Top management teams (TMT) at multinational enterprises (MNE) need to manage the complexity of geographically dispersed operations and cope with the demands of a multitude of international stakeholders. One way in which MNEs respond to such pressures is to raise the international profile of the $\mathrm{TMT}^{1}$, particularly by seeking top managers with international experience or with a foreign nationality (Athanassiou \& Nigh, 2000; Heijltjes, Olie, \& Glunk, 2003; Kirca, Hult, Deligonul, Perryy, \& Cavusgil, 2012; Luo, 2005). In literature on the globalization of MNEs it has been argued that the recruitment of foreign TMT members indicates a readiness to transform into truly global organizations (Bartlett \& Ghoshal, 1989; Derr \& Oddou, 1993; Prahalad \& Lieberthal, 1998) and is a prerequisite to cope effectively with the global-local dichotomy (Ghemawat, 2011). Indeed, recent studies have shown that internationalization of TMTs is an important feature of the internationalization process and, under certain conditions, has a positive impact on MNE performance (Kaczmarek \& Ruigrok, 2013; Nielsen, 2010; Nielsen \& Nielsen, 2013; Schmid \& Dauth, 2014).

Some recent studies suggest that there has been a substantial overall increase in appointments of foreign nationals to top executive positions over the last two decades (Davoine \& Ravasi, 2013; Ruigrok \& Greve, 2008; Staples, 2008; Van Veen \& Marsman, 2008). Countries such as Switzerland and the Netherlands, which have a relatively high density of large and geographically diversified MNEs, have been leading the way (Ruigrok \& Greve, 2008; Van Veen \& Marsman, 2008). Meanwhile, TMT internationalization has been comparatively sluggish in countries such as the UK, Germany, and France, and hardly traceable in countries like Spain and Italy (Van Veen \& Marsman, 2008).

Understanding the antecedents of TMT composition is vital for two main reasons: (1) it adds contextual knowledge to our understanding of TMTs' effects on organizational outcomes, and (2) it enables us to understand why seemingly optimal TMT configurations do 
not emerge equally across all firms. The literature on top managers' international experience, which examines how international assignment experience supports strategy implementation and decision-making at MNEs (e.g. Athanassiou \& Nigh, 2002; Bartlett \& Ghoshal, 1992; Carpenter, Sanders, \& Gregersen, 2001; Daily, Certo, \& Dalton, 2000; Gregersen, Morrison, \& Black, 1998; Reuber \& Fischer, 1997; Sambharya, 1996), serves as a good illustration. In this literature, several studies have shown that international assignment experience is likely to impede managers' career progress (e.g. Dickmann \& Harris, 2005; Feldman \& Thomas, 1992), making it more difficult for managers with international experience to progress to TMT positions. At the same time, international experience provides those managers who progress to the top with a valuable and potentially performance-enhancing resource (Carpenter, et al., 2001; Daily, et al., 2000). Carpenter, et al. (2001) and Daily, et al. (2000) discuss how a broad understanding of the antecedents of TMT international experience contributed to the development of their studies as well as to the interpretations of their findings.

In the evolving literature on TMT diversity, the findings of recent research suggest that TMTs comprising multiple nationalities are a potentially valuable resource (Kaczmarek \& Ruigrok, 2013; Nielsen \& Nielsen, 2013). At the same time, the antecedents of foreign TMT appointments remain a blind spot that limits our understanding of these findings. Key reasons why the international market for executives has gone largely unnoticed may be that (1) the international market for executives has emerged gradually and unevenly (Davoine \& Ravasi, 2013; Gillies \& Dickinson, 1999; Staples, 2007), and (2) we have previously lacked knowledge about the importance of TMT nationality diversity in the internationalization process of MNEs (Nielsen \& Nielsen, 2011; Schmid \& Dauth, 2014).

A few prior studies have investigated the presence and diversity of foreign TMT members at MNEs and described some possible antecedents of TMT internationalization (Greve, Nielsen, \& Ruigrok, 2009; Heijltjes, et al., 2003; Staples, 2007; Van Veen \& 
Marsman, 2008). However, no studies to date have developed and tested a comprehensive model of organizational and individual-level factors that are associated with the appointment of foreign nationals to TMT positions. The main objective of our study is therefore to fill this gap and identify antecedents of MNEs' propensity to internationalize the TMT.

As the dependent variable in this study is the nationality of appointed TMT members, our empirical model provides insights into the circumstances associated with the appointment of foreign nationals. This empirical approach implies that we study 'selective entry into a team,' i.e. we observe only the candidates that were selected for executive positions, as described in Boone, Van Olffen, Van Witteloostuijn, and De Brabander (2004). By choosing this approach, we make two key assumptions about the underlying selection process: (1) the MNEs in our sample have both domestic and foreign nationals in their candidate pools as they appoint new TMT members, and (2) the control variables in our model, such as firm size, TMT tenure, and the pre-appointment proportion of foreign TMT members, account for systematic variations in MNEs' candidate pools.

At the same time, our empirical model benefits from an important advantage over alternative specifications. While information about the nationalities of shortlisted candidates would have made it possible to directly model the selection decision, such shortlists are notoriously difficult to objectively define and assemble based on external observation and are likely to lack comparability across firms and over time (cf. Magnusson \& Boggs, 2006). Instead, our model distinguishes the circumstances associated with firms that appoint foreign candidates and those that appoint domestic candidates, as a proxy for the underlying hiring decision, thus avoiding the potentially confounding effects of incorporating candidate shortlists into the model.

This study makes two primary contributions to the literature. First, we shed light on the important link between the upper echelons (UE) perspective and international business research (Athanassiou \& Nigh, 2000; Carpenter, Geletkanycz, \& Sanders, 2004). We draw 
attention to the divergent forces in MNEs that determine the demand for executive candidates and thereby influence the configuration of TMTs over time.

Second, we show how a multilevel approach can be employed to improve our understanding of TMT appointment decisions, in line with Hambrick's (2007) call to extend UE research by examining the mechanisms of TMT composition. Understanding the multilevel sources of TMT composition preferences makes it possible to build more comprehensive and better informed models in future UE research. As discussed by Adams, Hermalin, \& Weisbach (2010) and Hambrick (2007), TMT structure and composition are often inaccurately treated as exogenous predictors of performance and other organizational outcomes in the empirical UE literature. The reluctance in existing research to consider why different governance structures and hiring preferences emerge across firms has limited our understanding of the linkages between structural governance features and organizational outcomes. Our study constitutes a step towards bridging this gap. We shed light on TMT composition preferences across MNEs and show how the presence of foreigners at TMT level varies with the combination of circumstances that each firm is faced with.

The rest of this paper proceeds as follows: First, we theoretically examine the drivers and barriers of foreign executive appointments and position the paper in the current literature. This is followed by the development of four hypotheses corresponding to our model of the determinants of foreign executive appointments. Subsequently, we employ a longitudinal and multi-country dataset to test the impact of the hypothesized predictors at three different levels (i.e. individual, year, and organization level) on the appointment of foreign candidates to TMT positions. Finally, we discuss the implications of our empirical findings as well as the theoretical and methodological contributions of this study to UE and IB research. 


\section{THEORY AND HYPOTHESES}

\section{The Benefits and Costs of an International TMT}

The establishment and subsequent operation of economic activities across multiple countries pose substantial challenges to MNEs. The costs and disadvantages that MNEs face in host markets relative to local firms are commonly referred to as liabilities of foreignness (Zaheer, 1995). They include the costs of physical distance, the costs of unfamiliarity with local institutional environments, the costs associated with negative inclinations towards foreign firms, as well as costs imposed by the home country in the internationalization process. These costs increase the uncertainty of operating in a foreign environment relative to the domestic environment. High levels of uncertainty imply that a large volume of complex and non-routine problems will be referred to the TMT (Thompson, 1967; Vermeulen \& Barkema, 2002) and stretch TMTs' capacities in terms of information-processing, resourceseeking, and legitimacy-building. Thus, to overcome liabilities of foreignness, MNEs must seek ways to effectively deal with and counteract the added uncertainty associated with operations in foreign markets. Appointments of foreign nationals to the TMT have three distinct and crucial functions that support MNEs' efforts to mitigate uncertainty in the internationalization process and overcome liabilities of foreignness.

First, MNEs can increase their information-processing capacities by hiring TMT members whose abilities to process information complement those of existing team members and are congruent with the MNE's information-processing requirements (Sanders \& Carpenter, 1998). Foreign executives are often viewed as a source of superior informationprocessing capacities related to foreign markets or regions that become increasingly important to the MNE (Greve, et al., 2009). Luo (2005) argues that foreign top managers also possess a unique type of internationally deployable expertise, which goes beyond knowledge of one or more specific foreign markets, enabling the MNE to make better use of its firm-level international experience. A more nuanced view is put forward by Dahlin, Weingart, and 
Hinds (2005), who show that high levels of nationality diversity increase the range of information use relative to moderate diversity levels, whereas the depth of information use peaks at an intermediate level of nationality diversity and decreases at higher diversity levels. Overall, MNEs can potentially benefit from added information-processing capacities by appointing foreign TMT members, but the realization of such benefits depends on whether the foreign candidates' information-processing capacities complement those of incumbent team members and whether they match the firm's information-processing needs.

Second, MNEs can employ foreign TMT members to extend their resource-seeking capacities and thereby gain access to a wider network of knowledge, resources, and opportunities. An international advice network is a key resource and a potential source of knowledge advantages for internationalizing MNEs (Athanassiou \& Nigh, 1999). If TMT members have strong network positions, firms can draw upon external resources and opportunities that for example increase the number and quality of decision alternatives or help to accurately assess the value of different options in decision-making processes (Hillman, Cannella, \& Paetzold, 2000; Pfeffer \& Salancik, 1978). Foreign TMT members possess contact networks that are typically more far-reaching than the networks of domestic executives, thus providing MNEs with access to a wider range of advice, resources, and opportunities in the internationalization process (Athanassiou \& Roth, 2006).

Third, MNEs can build legitimacy in foreign markets and signal commitment to the causes and interests of their international stakeholders by appointing foreign TMT members. TMT appointments are widely observed symbolic actions that can help MNEs to establish legitimacy and gain credibility among key stakeholders in foreign markets (Gong, 2006; Miller \& Triana, 2009; Milliken \& Martins, 1996). Particularly in the case of foreign expansion, which is accompanied by growing internal and external information asymmetries, signaling can be a powerful and important bridging mechanism to reduce the perceived uncertainty associated with increasing foreign market involvement (Sanders \& Carpenter, 
1998). Different nationalities in the upper tiers of management denotes a strong commitment to international markets and stakeholders across the MNE's geographical locations and a readiness to trade in local attachment in response to the demands of global operations.

Despite the potential advantages of raising the international profile of the TMT, the internationalization of key organizational teams is also associated with economic costs and risks (Lazear, 1999). One explanation of firms' reluctance to appoint foreign TMT members may be found in the theory of organizational and relational demography (Pfeffer, 1983; Tsui, Egan, \& O'Reilly, 1992). This theory holds that demographic characteristics affect the strength of relationships between individuals and organizations (organizational demography) and relationships within groups or units (relational demography). Empirical research has shown that the degree of demographic (dis)similarity between individuals and dominant groups or cohorts within an organization affects the strength of relationships and the level of organizational attachment (for reviews see: Joshi, Liao, \& Roh, 2011; Williams \& O’Reilly, 1998). Further research has shown that organizational demography can also affect TMT membership (e.g. Boone, et al., 2004; Wagner, Pfeffer, \& O’Reilly, 1984). The lack of organizational attachment resulting from demographic differences is associated with costs and risks, such as slow integration and socialization, low levels of cohesion, and high exit probability. Based on the logic of organizational demography, MNEs are likely to adopt a cautious approach to TMT diversity, as they strive to avoid potentially dysfunctional and disruptive team constellations.

Besides the costs and risks associated with increasing demographic differences, it is also likely that the job-matching process is more complex and cumbersome across borders than within a domestic environment. First, it is typically difficult and costly for MNEs to closely monitor managerial talent pools in other countries due to limited resources and crossborder information constraints (Mellahi \& Collings, 2010). Many MNEs are reluctant to incur such costs, as domestic TMT candidates are customarily perceived to fit well with 
organizational culture and value systems. Furthermore, the appointment of foreign executives may be perceived as a transfer of economic power and resources into foreign hands. Even at high degrees of internationalization, many MNEs retain a strong association between the firm's indigenous national heritage and its organizational identity. This can serve as a substantial barrier to the internationalization of TMTs.

Second, aspiring executives may associate the prospect of a TMT position at a foreign MNE with greater risk than equivalent positions at domestic MNEs. This means that some TMT candidates impose their own mobility constraints, based on factors such as pay level differences, social capital immobility, cultural distance, and language barriers. Language and cultural barriers are likely to discourage many talented executive candidates from leaving their well-known domestic environment for a less certain and riskier venture abroad. Furthermore, the perceived value of executives' human and social capital may differ across borders, as past achievements in the home country and domestic network connections provide less intrinsic support in a foreign environment. This raises the likelihood that foreign TMT members will be judged on immediate achievements, whereas their domestic counterparts may be given more slack based on past achievements and credentials. For the above reasons, foreign candidates may demand more favorable contractual terms than their domestic counterparts, effectively raising the relative costs of hiring foreign TMT candidates. Provided that useful alternatives exist in the domestic executive labor market, the imperfect mobility characteristics of foreign candidates may deter a substantial proportion of MNEs from seeking executive candidates abroad.

Our theoretical review suggests that there are benefits and costs of internationalizing TMTs. Thus, MNEs are likely to face countervailing pressures in the decision to appoint foreign or domestic candidates to TMT positions. As a result of these countervailing pressures, we hypothesize that MNEs exert demand for foreign TMT candidates in response to circumstances that (1) particularly emphasize the need for a foreign TMT member, or (2) 
distinctly suppress the actual or perceived costs and risks associated with the appointment of a foreign candidate.

\section{Antecedents of Foreign TMT Appointments}

In our development of hypotheses, we elaborate on factors at individual and firm level that alone or in combination may have a decisive influence on the MNE's decision to appoint a foreign TMT candidate. At the individual level, we relate the experiential characteristics of TMT candidates and the functional characteristics of TMT positions to the probability of appointing a foreign candidate. At the firm level, we argue that the propensity to appoint foreign TMT members is affected by the MNE's performance in the preceding year as well as the MNE's degree of internationalization. These hypotheses combine into a multilevel model of TMT appointment decisions that we subsequently test empirically. Figure 1 provides a graphical illustration of our research model.

INSERT FIGURE 1 ABOUT HERE

In the first cluster of hypotheses, we propose that experiential background is likely to influence the relative attractiveness of TMT candidates. As MNEs consider domestic and foreign candidates for TMT positions, they are likely to associate the foreign candidates with a higher risk profile. Thus, MNEs will attempt to offset the additional risks of appointing foreign TMT members by closing the information gap via other mechanisms and thereby reduce the risk of adverse selection. Two main types of experiential characteristics are expected to reduce the information gap, namely the candidate's generic and firm-specific experience profiles. 
Generic experience refers to the candidate's age, which is generally associated with traits that reduce the risk of adverse selection and socialization failure in a new team, such as more socially oriented and unselfish work behavior (Ng \& Feldman, 2008). Candidates in the upper age cohorts have also revealed more information about their cognitive abilities and working capacities to the labor market (Murphy, 1986). This additional information partially offsets the inherent information disadvantage associated with foreign candidates. Furthermore, older candidates may benefit from the diversity and longevity of their contact networks to verify their credentials and suitability for an executive position abroad. Overall, these arguments suggest that factors associated with higher age both enhance and validate information about foreign candidates' career credentials, thereby reducing the MNE's risk of appointing a foreign TMT candidate.

Hypothesis 1a: An executive appointee's age is positively associated with the likelihood that he/she is a foreigner.

Prior to a TMT appointment decision, MNEs can directly observe internal candidates' managerial abilities and efforts. This is likely to reduce the information gaps that are typically associated with foreign candidates due to lower verifiability of foreigners' background credentials (Perlmutter \& Heenan, 1974) and higher monitoring costs of geographical distance (Mellahi \& Collings, 2010). At the same time, research has shown that information asymmetries are exacerbated when firms consider executive candidates from outside the organization (e.g. Harris \& Helfat, 1997; Zajac, 1990). According to Petersen and Saporta (2004), readily observable demographic characteristics matter less in recruitment decisions if firms already possess information about a candidate's unobservable characteristics and performance inside the firm. 
Overall, internal firm tenure is associated with lower integration costs and less performance uncertainty. Thus, the likelihood of appointing a foreign TMT candidate increases if the candidate has longer tenure within the firm.

Hypothesis 1b: An executive appointee's intra-firm tenure is positively associated with the likelihood that he/she is a foreigner.

In the second cluster of hypotheses, we propose that the type of function within a TMT is another key determinant of the propensity to appoint a foreign top manager. Extending the general notion that foreigners enhance information-processing, resource-seeking, and legitimacy-building capacities at TMT level, we argue that such requirements are not necessarily evenly distributed across the different functions within a TMT.

A key distinction is made in the literature between functions that focus on achieving efficiency within the boundaries of the organization, referred to as throughput-oriented functions, and functions that emphasize productive activities that cross boundaries between the organization and external entities, referred to as input- and output-oriented functions (Bunderson, 2003; Datta \& Guthrie, 1994; Datta \& Rajagopalan, 1998; Hambrick \& Mason, 1984; Rajagopalan \& Datta, 1996). To avoid confounding effects, we treat functions with geographically oriented responsibilities as a distinct category. Finally, we define a separate category for general and unspecified management roles and use this as a control category.

Throughput-oriented TMT functions focus on efficiency improvements in the transformation process within an organization (Hambrick \& Mason, 1984). Thus, these functions comprise roles in production, process innovation, accounting, law, and human resources. These are roles that require a thorough understanding of the core needs of the MNE in the value creation process and the development of firm-specific skills and informationprocessing capacities that support operational continuity and efficiency (Chaganti \& 
Sambharya, 1987; Datta \& Guthrie, 1994). In addition, such roles are likely to require access to networks, resources, and institutions in the MNE's home country to ensure a stable relationship between the firm and its primary stakeholders and operating environment. As MNEs seek to minimize the disruptive impact of succession on the firm's operations (Helfat \& Bailey, 2005; Kesner \& Sebora, 1994), we expect throughput-oriented role requirements to produce a preference for organizationally and culturally embedded homecountry oriented individuals. In addition, as the internationalization of firm activities typically precedes the internationalization of the workforce (Lazear, 1999), even highly internationalized MNEs are likely to find that their internal pipeline of throughput-oriented TMT candidates predominantly consists of domestic nationals.

Hypothesis 2a: Appointment to a throughput-oriented role is negatively associated with the likelihood that an executive appointee is a foreigner.

Input- and output-oriented TMT functions emphasize the pursuit of market growth opportunities and optimization of the supplier base. This includes product innovation, logistics, supply chain, marketing, sales, and communication roles. While most previous studies have emphasized the notion of output-oriented roles (e.g. Bunderson, 2003), we combine input- and output-oriented TMT roles for two main reasons: (1) there are common denominators that generally apply to boundary-spanning roles, regardless of whether such roles are input- or output-oriented, and (2) we observed during data collection that input- and output-oriented TMT roles were often combined at the firms in our study (e.g. Head of Supply Chain and Marketing; Head of Sales and Logistics), which made our decision seemingly logical. It is also worth noting that the vast majority of TMT roles in this category have a primary output orientation. 
Input- and output-oriented TMT members are responsible for the pursuit of external growth opportunities as well as product and market adaptations (Hambrick \& Mason, 1984). Such roles imply the management of relations across organizational boundaries at the interface between the MNE and external suppliers, customers, and partners. The literature on boundary-spanning individuals in organizations suggests that such individuals need to possess a combination of specialist, domain-specific skills and a "cosmopolitan" orientation, i.e. a set of generic skills that facilitate communication and knowledge transfer across boundaries (Tushman \& Scanlan, 1981, and 1981a). This combination of skill sets is to a relatively large extent transferable across organizational and geographical contexts, which means that MNEs are unlikely to display an inherent preference for domestic TMT candidates in appointments to such roles. The use of international candidate pools increases the likelihood of finding a TMT candidate with greater function-specific knowledge and stronger generic boundaryspanning skills. Thus, we expect MNEs to display a higher propensity to appoint foreign candidates to input- and output-oriented TMT roles.

Hypothesis 2b: Appointment to an input- or output-oriented role is positively associated with the likelihood that an executive appointee is a foreigner.

We define TMT roles with geographical or regional responsibilities as an additional type of TMT function. Such TMT roles primarily require candidates to possess market- or region-specific knowledge and can therefore clearly be distinguished from the two preceding types of TMT functions. At TMT level, positions with geographical responsibility typically comprise multiple countries and frequently refer to major regions such as North America, Europe, or Southeast Asia.

There are numerous reasons why MNEs may assign responsibility for overseas divisions to host-country nationals, including the need for country- and region-specific 
knowledge and the need to gain legitimacy in local environments (Harzing, 2001). Research has found that host-country nationals are typically preferred as subsidiary top managers in countries and regions with lower cultural and institutional distance from the MNE's home country (Gaur, Delios, \& Singh, 2007; Gong, 2003). In the case of corporate-level TMT members with geographical or regional responsibilities, it is likely that the overseas activities require high degrees of local adaptation or that there are other reasons for giving the overseas division a relatively high degree of autonomy. This means that MNEs are most likely to benefit from the country- or region-specific knowledge, resource access, and legitimacybuilding capabilities of foreign nationals, rather than assigning such responsibilities to a parent-country national. Thus, we expect that MNEs will particularly seek foreign TMT candidates to fill such roles.

Hypothesis 2c: Appointment to a role with geographical/regional responsibility is positively associated with the likelihood that an executive appointee is a foreigner.

Highly international MNEs face diverse competitive environments and a geographically dispersed set of stakeholder groups with vastly diverging interests. Thus, the degree of internationalization of MNEs is often employed in the literature as a proxy for complexity (e.g. Calori, Johnson, \& Sarnin, 1994; Carpenter, 2002; Hitt, Hoskisson, \& Ireland, 1994; Sanders \& Carpenter, 1998). MNEs that face high levels of complexity will seek to match the demands of the external environment with the capabilities of the TMT and its members (Hambrick, Finkelstein, \& Mooney, 2005), in line with the notion of 'matching managers to strategies' (Gupta \& Govindarajan, 1984; Szilagyi \& Schweiger, 1984).

Recent research suggests that the complexity of MNEs' international operations are reflected in the presence of foreigners on TMTs, albeit not to an extent that is immediately equivalent to the firms' overall internationalization levels (Heijltjes, et al., 2003, Van Veen \& 
Marsman, 2008). This discrepancy is arguably attributable to temporal and structural rigidities that delay and restrict firms' utilization of non-domestic managerial talent pools during the internationalization process (Lazear, 1999; Mellahi \& Collings, 2010; Ruigrok \& Greve, 2008), including the notions of risk aversion and home-country bias in the executive appointment process, as well as executive candidates' own individual mobility constraints. Even though past studies suggest that changes in MNE international posture and the appointment of foreign TMT members are not necessarily concurrent events, we expect a higher propensity to appoint foreign TMT members at more internationalized MNEs.

Hypothesis 3: The overall degree of firm internationalization is positively associated with the likelihood that an executive appointee is a foreigner.

Carpenter and colleagues (2004) advance the notion of a recursive link between firm performance and TMT composition. Indeed, Rost, Salomo, and Osterloh (2008) show that sublevel firm performance prompts changes in TMT composition, and that low-performing firms display a greater risk-taking propensity in executive appointment processes. The combination of a higher risk-taking propensity and a need to make performance-enhancing changes may induce the appointment of foreign TMT candidates.

MNEs that extend their international presence beyond the scope of their capacities at corporate headquarters are prone to face negative performance consequences (Vermeulen \& Barkema, 2002). Low-performing MNEs have often overestimated their internal capacities and underestimated the extent of liabilities of foreignness in the internationalization process. A period of sublevel performance is likely to trigger a transformation process at TMT level to restore parity between organizational complexity and the TMT's information-processing, resource-seeking, and legitimacy-building capacities. Such firms are likely to appoint foreign 
executives, who can enhance the quality of information-processing, facilitate access to new external resources, and support legitimacy-building in international stakeholder environments.

Hypothesis 4: MNE performance in the preceding period is negatively associated with the likelihood that an executive appointee is a foreigner.

\section{DATA AND METHODS}

\section{Sample and Data}

To conduct this study, we employ a dataset covering all 1,446 TMT appointments between 2001 and 2005 at the largest non-financial MNEs headquartered in Denmark, Finland, the Netherlands, Norway, Sweden, Switzerland, and the UK. The seven countries were selected as comparatively open economies with corporate reporting practices that widely matched the data requirements for this study at the time of data collection. The study period from 2001 to 2005 covers arguably the most recent period of relative stability in the European economy and a period of gradually increasing TMT internationalization across Europe. It is therefore considered to be an adequate period to conduct a study on the antecedents of TMT internationalization. The 360 firms included in the study comprised all firms that were headquartered in the seven countries and that had at least $€ 500 \mathrm{~m}$ turnover and at least 1000 employees at year-end 2005, as per data retrieved from the ThomsonONE database. Firms that did not exist throughout the study period and firms that did not provide any information on TMT membership were excluded from the study. The final sample consisted of $6 \%$ Danish firms, 9\% Finnish firms, 11\% Dutch firms, 5\% Norwegian firms, 11\% Swedish firms, $14 \%$ Swiss firms, and $44 \%$ UK firms that met the inclusion criteria. The average MNE in our sample had approximately $€ 6 \mathrm{bn}$ annual revenues and generated $61 \%$ of the revenues abroad.

Executive profile data and firm-level data were collected retrospectively from annual reports, corporate websites, various biographical databases, and direct e-mail contact with the 
sample firms. The assembly and coding of data followed a detailed set of pre-defined rules and guidelines derived from common procedures and variable definitions described in upper echelons research (e.g. Carpenter \& Fredrickson, 2001; Hambrick \& Mason, 1984; Michel \& Hambrick, 1992; Tihanyi, Ellstrand, Daily, \& Dalton, 2000). Firm performance data, i.e. return on assets (ROA), was retrieved from ThomsonONE.

The concept of nationality is central to this study, as it distinguishes foreign executives, who move across borders and assume TMT positions at foreign MNEs, and domestic executives, who occupy TMT positions within their home country environment. To make the distinction between domestic and foreign executives, we assign country affiliations to the MNEs in our sample based on the primary location of their headquarters. Nationality is a primary vehicle for social identification and an indicator of inherent cultural and geographical orientations (Salk \& Shenkar, 2001). It has both cognitive and symbolic properties that are attractive in the context of this study. A nationality is an approximation of a set of values, demeanors, attitudes, and behaviors associated with a particular national culture (Hambrick, Davison, Snell, \& Snow, 1998; Hofstede, 1991). In addition, due to the strong impact of nationality on personality and identity and the close proximity of nationality to the real underlying values and cognitions of individuals (Triandis \& Suh, 2002), it is a particularly salient construct in international contexts and team settings (Hambrick, et al., 1998).

We use the TMT as a generic term for the highest level of corporate management in the MNEs in our sample. We generally rely on firms' self-reported TMT definitions. In cases where firms reported two or more levels of top managers, we selected the core team (i.e. the CEO and immediate subordinates) to define the TMT, as long as the team consisted of at least three members (i.e. the CEO and at least two other members).

In Switzerland, the TMT is typically referred to as the Geschäftsleitung. The TMT has operational responsibilities which are separated from the work of the board. However, the 
CEO is often a member of the board of directors, functioning as a representative of the management. In the UK, the most senior management level (most often referred to as the executive committee) typically consists of the executive members of the board of directors, but may also comprise additional top managers who are not members of the board of directors. Dutch TMTs are referred to as the Raad van Bestuur. At the time of our investigation there were no overlaps of board and TMT membership at Dutch firms. In the Nordic countries, the TMTs are generally referred to as management boards or management committees. As in the case of Switzerland, CEOs of Nordic firms often combine the executive function with a seat on the board of directors.

\section{Dependent Variable}

Foreign TMT appointment. The dependent variable was coded as 1 if a new TMT member was a foreigner, i.e. if the nationality of the TMT appointee was different from the country of the MNE's headquarters. Foreign TMT appointments account for 28.7 percent of all new TMT appointments in our sample.

\section{Independent Variables}

Age and organization tenure. We recorded the age and organization tenure of TMT appointees in years at the time of entry to the TMT.

Functional responsibilities within the TMT. The operationalization of this variable proceeded in two steps. First, based on information from annual reports and corporate websites, the basic descriptions of TMT members' functional responsibilities were reduced into a broad classification scheme comprising 27 generic functional descriptions. In a second step, two of the authors independently assigned the 27 generic functional areas to the four theoretically derived categories. There was initial disagreement in only two of the 27 classes 
$($ Cohen's Kappa $=0.90)$. For both cases, raters agreed upon a classification after short discussion. This resulted in dummy variables for input/output functions (e.g., marketing, investor relations), throughput functions (e.g., operations, human resources), regional responsibilities (e.g., Asia, Europe), and general management (e.g., CEO, general manager). Note that more than one function was coded for a TMT member whenever the individual had several explicitly defined roles within the TMT.

Degree of internationalization. We measured the degree of internationalization as the ratio of foreign sales divided by total sales (FSTS) to indicate MNEs' relative dependence on foreign versus domestic markets. FSTS data was obtained from annual reports.

Return on assets. We used information retrieved from ThomsonONE to determine MNEs' annual ROA during the study period, calculated as the net income divided by total assets. We employed the ROA in the year prior to a given TMT appointment $\left(\mathrm{ROA}_{\mathrm{t}-1}\right)$ as the independent variable to predict the probability of appointing a foreigner.

\section{Control Variables}

At the individual level, we used dummy variables to control for the gender of TMT appointees (female $=1$, male $=0$ ). We also used dummy variables to control for the year of appointment. This variable accounts for possible longitudinal trends in the appointment of foreign TMT members within the study period. To control for structural and other systematic differences between the TMTs in our sample at the time of a new appointment, we controlled for TMT size (measured as the number of TMT members), mean TMT age (in years), mean TMT tenure (in years), and the percentage of foreign TMT members in the year prior to the appointment. We also included dummy variables for MNEs' country of origin and measured firm size as total annual revenues. 
Furthermore, we used dummy variables to control for primary industry attachment, as our sample of non-financial firms face competitive situations and stakeholder pressures that are likely to vary at the industry-level. We classified all 360 firms into 24 industry groups based on a combination of stock exchange classifications and Standard Industry Classification (SIC) codes, drawing on the procedure described in Amburgey and Miner (1992).

\section{Methods}

Analytic strategy. Our model included three levels of analysis: (1) TMT member, (2) year of assignment, and (3) firm. The model reflects a hierarchical data structure containing these three levels, as all appointments of TMT members are nested within years, which in turn are nested within firms (Bliese, 2000). The probability of assigning a foreigner to the TMT (i.e. the dependent variable) is contingent on predictors at these three levels. The lowest level includes characteristics of each single appointment. At this level, we hypothesize that TMT members' experiential characteristics and functional responsibilities are relevant predictors of the probability of assigning a foreigner to the TMT. Second, if a firm makes multiple TMT appointments in a given year, each TMT appointment is affected by organizational characteristics that are relevant to that particular year. For example, a firm's performance arguably has an impact on the organizational setting in which TMT appointments are made in the subsequent year. Thus, the second level is necessary to describe time-variant firm characteristics. Lastly, the third level captures stable firm characteristics that do not vary during the study period. For example, country of origin and industry are stable characteristics that are likely to affect all executive appointments at a given firm.

Our dependent variable is a binary outcome (foreign/domestic). Therefore, we applied a multilevel model for binary data (multilevel logit model; see, for example, Guo and Zhao, 2000). Since we have three levels of analysis, the basic model without any predictor variables (i.e. the null model) can be described by the following multiple equation system: 
$\log \left[\frac{p_{i j k}}{\left(1-p_{i j k}\right)}\right]=\eta_{i j k}=\pi_{0 j k} \quad$ (level 1 model $)$

$\pi_{0 j k}=\beta_{00 k}+r_{0 j k} \quad$ (level 2 model)

$\beta_{00 k}=\gamma_{000}+u_{00 k} \quad$ (level 3 model)

with $\mathrm{p}_{\mathrm{ijk}}$ as the probability of appointing a foreigner to a firm's TMT. This model is subsequently extended by adding predictors at each of the three levels. Note that due to the dichotomous dependent variable, there is no random error at level 1 , as the level 1 variance is determined completely by the estimated value for $\eta_{\mathrm{ijk}}$ (Hox, 1995).

We first estimated a model that contains control variables only at all three levels. Then, we added predictors at level 1 to test Hypotheses 1a-1b and Hypotheses 2a-2c. Finally, we added predictors at levels 2 and 3 to test Hypotheses 3 and 4.

Centering Decisions. In ordinary least squares regressions, centering issues are relatively straightforward in that researchers may decide whether or not variables should be mean-centered, i.e. subtracting a variable's overall mean from each case of that variable (Aiken \& West, 1991; Echambadi \& Hess, 2007). Centering in multilevel models needs more attention, as lower level variables can be centered at the grand mean (CGM) or the deviation from a group's mean can be calculated (centering within clusters, CWC; Enders \& Tofighi, 2007). In the latter option, mean group values are calculated and the deviation between each case and case's group mean is computed. CWC removes all between-cluster variation and, thus, group-mean centered variables are uncorrelated with higher-level variables. Statistically, there is no correct choice between CGM and CWC and both give correct results (Kreft, 1995). However, both centering options produce parameter estimates that differ in value and also in meaning (Enders \& Tofighi, 2007). Centering decisions should therefore be based on the underlying research questions. 
First, if a level 1 predictor is of substantive interest, we center the predictor at its group-mean (CWC), as this form removes higher-level variance in a variable and gives pure estimates of level 1 variance. Second, control variables are added to the model using CGM, since effects of group-mean centered variables are orthogonal to higher-level variables and, thus, adding group-centered lower-level variables is not a means to control for their effect at a higher level. Third, as stated above, we hypothesize that the financial performance in the period prior to the appointment of a new TMT member is of relevance (Hypothesis 4). Here, we are specifically interested in ROA in t- 1 and not so much in the overall financial performance in the study period. Thus, we hypothesize a level-2 effect of ROA in t-1. We apply CGM of the lower-level variable (i.e. ROA in t-1), since we argue that the absolute ROA in t- 1 is of greater relevance than the deviation of a firm's ROA from its mean value (as would be the case when applying CWC).

For the degree of internationalization (measured as the ratio of foreign sales to total sales), we argue that the MNE's mean foreign sales ratio in the study period is a useful indicator of whether a firm is likely to appoint foreign TMT members (Hypothesis 3). To test the appropriateness of aggregating annual foreign sales (level 2) to a higher level (i.e. mean foreign sales, level 3), we calculated the intraclass correlation coefficient (ICC[1]) for this variable (Bliese, 2000; McGraw \& Wong, 1996). ICC(1) can be defined as the amount of between-group variance divided by the sum of between-group and within-group variance. This interpretation of the ICC(1) ranges between 0 and 1 and a high ICC(1) indicates that values within each group are very similar (low within-group variance), but differ across groups (high between-group variance). If ICC(1) is high, it is appropriate to aggregate lowerlevel values to a higher level (LeBreton \& Senter, 2008). We find an ICC(1) of 0.97 for the annual foreign sales ratios. This very high value shows that a firm's mean foreign sales is reliably measured by the average foreign sales ratio across the study period. Hence, we added the degree of internationalization, measured as mean foreign sales, as a predictor variable at 
level 3. Centering decisions at the highest level are less critical and comparable to centering in OLS regressions (Enders \& Tofighi, 2007). In our model, we enter all level 3 variables grandmean centered.

Missing data. Study variables showed missing values that ranged between zero and 14.1 percent of missing data (gender and ROA in t-1, respectively). We applied multiple imputation (Rubin, 1987; Sinharay, Stern, \& Russell, 2001) to avoid a loss of information and statistical power that is inherent in the common procedure of listwise deletion, which means that all cases are excluded that have one or more missing values in any of the covariates (see for example, Graham, 2009; Roth 1994; Schafer \& Graham, 2002). Since the nested data structure must be accounted for when imputing data, we applied an imputation algorithm described by Schafer (2001) and Schafer and Yucel (2002) that is specifically designed for clustered data.

We imputed data in a two-step procedure. First, we imputed missing values on level 2 (year), based on the clustering at level 3 (organization). Second, we imputed level 1 data (individual), taking into account clustering at level 2. Imputations were conducted with the PAN extension package (Schafer, 1997) using the R language for statistical computing (R Development Core Team, 2008; the code is available on request). Based on recommendations by Fichman and Cummings (2003) and Sinharay and colleagues (2001), we created $m=5$ imputations. Datasets were stored and analyses were performed on each of the five datasets. Subsequently, we combined the results following the rules suggested by Rubin (1987). To check whether our findings were sensitive to the imputation of data, we estimated a reduced model based on listwise deletion and compared the results. The outcomes of the additional analysis pointed in the same direction and did not differ substantially from the results of the full model. 
For multilevel analyses, we used the HLM 6 software (Raudenbush \& Bryk, 2002). To avoid unwieldy models, we limited the number of random effects in that we modeled the intercepts as having randomly varying residuals (i.e. $r_{0 j k}$ and $u_{00 k}$ were estimated) and fixed the slopes (Snijders, 2005). Based on these considerations, the full mixed model with foreign TMT appointment as dependent variable can be expressed as (Equation 4):

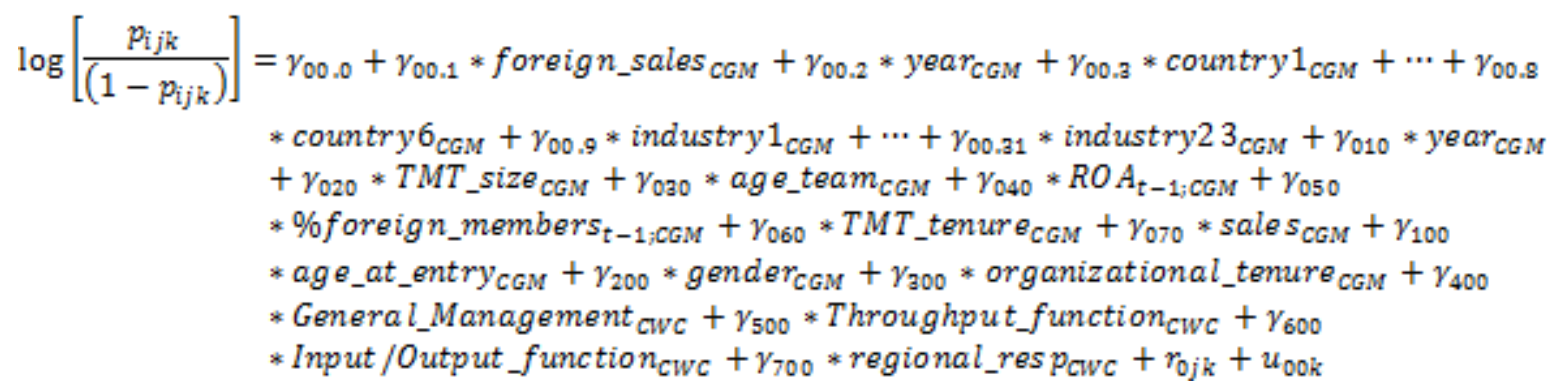

\section{RESULTS}

Table 1 displays means, standard deviations, and zero-order correlations among the study variables. Correlations among variables that are measured at level 1 are shown above the diagonal. Below the diagonal, the table depicts correlations between level-2 variables and aggregated level-1 variables. Note that the correlations shown in Table 1 do not account for the nested data structure (individuals in years in firms).

The control variables display largely expected relationships with the dependent variable. In the base model, being female is negatively associated with the likelihood of being appointed as a foreign TMT member. However, this effect becomes non-significant once we enter the predictors in the full model. One explanation of this observation may be the high correlation between gender and functional orientations. Table 1 shows that female TMT members are particularly likely to be employed in throughput-oriented functions and less likely to be found in input- and output-oriented functions. 
Hypothesis tests for foreign TMT appointments were conducted using a multilevel logit model with three levels (see Table 2). Model 1 contains the set of control variables only. To test Hypotheses 1a, 1b, 2a, 2b, and 2c, Model 2 introduces age, organization tenure, and four dummy variables at the individual level (level 1), which capture the experiential characteristics and functional responsibilities of newly appointed TMT members.

Hypothesis 1a proposes a positive relationship between the age of TMT appointees at the time of entry and the probability that a TMT appointee is a foreigner. Model 2 shows that this hypothesis is supported (gamma $=0.064$, standard error $[$ s.e. $]=0.011, \mathrm{p}<0.001)$. Hypothesis $1 b$, which predicts that organization tenure is positively related to the likelihood that a TMT appointee is a foreigner, is not supported by the data $($ gamma $=-0.016$, s.e. $=$ $0.009, \mathrm{p}>0.05)$

Hypothesis $2 \mathrm{a}$ proposes a negative relationship between appointment to throughput functions and the probability that the TMT appointee is a foreigner. This is not supported by the data. The corresponding gamma coefficient is negative, but it is above the $5 \%$ Type I error threshold $($ gamma $=-0.494$, s.e. $=0.298, \mathrm{p}>0.05)$. Hypothesis $2 \mathrm{~b}$ predicts a positive association between appointment to input/output functions and the likelihood that a TMT appointee is a foreigner. Similarly, Hypothesis 2c proposes a positive relationship between geographical TMT responsibilities and the probability that a TMT appointee is a foreigner. Results in Model 2 support both hypotheses (gamma $=0.646$, s.e. $=0.263, \mathrm{p}<0.05[\mathrm{H} 2 \mathrm{~b}]$ and gamma $=2.432$, s.e. $=0.399, \mathrm{p}<0.001[\mathrm{H} 2 \mathrm{c}]$, respectively $)$.

In Hypotheses 3 and 4, we propose relationships between higher-level variables on the probability of appointing a foreigner to the TMT. Hypothesis 3 states that the degree of internationalization is positively associated with the likelihood of appointing a foreigner. As described above, we conceptualized the degree of internationalization as a level-3 variable measured as MNEs' mean foreign sales ratio in the study period. Results in Model 3 support 
this hypothesis $($ gamma $=1.560$, s.e. $=0.373, \mathrm{p}<.001)$. Finally, Hypothesis 4 suggests that $\mathrm{ROA}_{\mathrm{t}-1}$ is negatively associated with the probability of appointing a foreign TMT candidate. This is also supported in Model 3 (gamma $=-0.018$, s.e. $=0.008, \mathrm{p}<.05$ ).

As a robustness test, we additionally estimated all models using Kogut and Singh's (1988) measure of cultural distance between the MNE's home country and the nationality of the TMT appointee as an alternative specification of the dependent variable. The strength and direction of the hypothesized effects were very similar to the logit model, albeit with somewhat weaker significance levels. The results of these additional analyses are not reported in this article, but they are available on request.

\section{DISCUSSION}

This paper extends previous efforts to bring together international business theory and the UE perspective (e.g. Athanassiou \& Nigh, 2000; Nielsen \& Nielsen, 2011; Tihanyi, et al., 2000) to further our understanding of the relationship between TMT composition and firm internationalization. Our findings highlight the multilevel antecedents of foreign TMT appointments and shed light on how MNEs respond to the countervailing forces of strategic expansion and local attachment in the internationalization process. Internationalizing MNEs appoint foreign TMT members for several reasons, such as to improve the quality of TMT information-processing, to draw upon a wider range of advice, resources, and opportunities in TMT decision-making, and to build legitimacy in international stakeholder groups. These benefits of foreign TMT membership help to reduce the uncertainty attached to MNEs' market-seeking and boundary-spanning activities. At the same time, the realization of such benefits is likely to require structural adjustments within the organization and a long-term perspective, as foreign TMT appointments are typically associated with high initial adaptation costs and less predictable outcomes. 
Our empirical findings highlight some of the specific circumstances that are associated with foreign TMT appointments. First, we observe that the appointment of foreigners is closely attached to the particular requirements of different types of TMT positions. Specifically, we find that foreign TMT members are likely to be placed in charge of MNEs' organizational and geographical boundary-spanning activities. Input- and output-oriented TMT functions primarily require the ability to process information, interact, and liaise at the interface between the MNE and its external environment, particularly in relation to customers and suppliers. Geographically oriented TMT functions predominantly require country- or region-specific skills and capabilities. Our findings show that MNEs display a relative preference for foreigners as boundary-spanners, regardless of whether the boundaries to be crossed are at the organizational or geographical level.

Meanwhile, we find that candidates' nationalities are less important in the case of appointments to throughput-oriented TMT roles. As throughput-oriented roles focus particularly on improving the efficiency of transformation processes within the MNE, we hypothesized that MNEs are likely to prefer TMT candidates with an attachment to the firm's home country. However, we do not find conclusive support for this hypothesis.

Overall, these findings suggest that MNEs hire foreign TMT candidates primarily due to the perceived superiority of their generic and location-specific information-processing, resource-seeking, and legitimacy-building capabilities, which are particularly required in boundary-spanning TMT roles. On the other hand, MNEs do not display a strong preference in terms of candidates' nationalities as they seek the firm-specific skills and continuity that are particularly required in throughput-oriented TMT roles. These outcomes provide evidence for divergent appointment patterns for different types of TMT functions, suggesting that MNEs associate foreign TMT candidates with a different set of information-processing, resource-seeking, and legitimacy-building abilities, as well as a different set of risk attributes, than their domestic counterparts. 
Second, we find some evidence that executive candidates' experience profiles are associated with the likelihood of a foreign TMT appointment. In line with our first prediction, our results show that foreign TMT appointments are positively associated with candidates' age. However, we do not find empirical support for the hypothesis that the likelihood of being appointed as a foreign TMT candidate increases with the length of intra-firm tenure. These findings complement our findings above pertaining to TMT functions, as they corroborate the notion that MNEs particularly value foreign TMT candidates' generic skills. Firm-specific skills, on the other hand, do not appear to give any relative advantage to foreign or domestic candidates in the appointment decision. It is likely that tenure within the firm levels the playing field between foreign and domestic TMT candidates, as candidates' nationalities matter less if the firm has been able to directly observe their managerial abilities and assess their suitability for a TMT position prior to appointment.

Third, our findings show that MNEs have a greater propensity to appoint foreign TMT candidates at higher degrees of internationalization. At the same time, we find that lowperforming MNEs are more likely to appoint foreigners to the TMT, suggesting that such appointments can be a response to pressures for radical change within the organization. Jointly, these findings suggest that there are strong countervailing forces in MNEs that determine the pace and extent of TMT internationalization. As MNEs internationalize, they are likely to routinely overstretch their internal capacities and incur high learning costs, which is reflected in declining firm performance at various stages of the internationalization process (Contractor, Kundu, \& Hsu, 2003; Vermeulen \& Barkema, 2002). Our findings suggest that the stages of performance decline in the internationalization process give rise to intensified pressures to appoint foreign TMT candidates. Such appointments counteract capacity deficits within the TMT and close perceived information gaps between the TMT and international stakeholders. Hence, these results support our core argument that foreign TMT appointments particularly materialize under circumstances that raise the need for the expertise, networks, 
and symbolic value of a foreign TMT member and that distinctly suppress the (actual and perceived) risks of hiring a foreign national relative to a domestic candidate.

At first glance, our findings appear somewhat at odds with the conclusions of Boone, et al. (2004), whose findings suggest that TMTs tend to 'close ranks' and select newcomers who are demographically and experientially similar to incumbent TMT members in circumstances that produce high levels of uncertainty or threaten the existence of the firm. However, these seemingly contradictory findings may also point to two separate logics that can effectively co-exist. Contrary to our study, Boone, et al.'s (2004) article focuses on dimensions of dissimilarity that are only to a limited extent observable at the surface-level. This means that the symbolic value of diversifying the TMT along these dimensions may be rather limited. Meanwhile, the signaling value of diversifying the TMT on surface-level dimensions is likely to be substantially greater.

Firms in distress may therefore decide to indicate to the market that changes are underway by appointing TMT candidates that are demographically dissimilar to incumbents in terms of surface-level characteristics (e.g. foreigners, females). However, at the same time they may 'close ranks' on other dimensions and appoint for example female or foreign TMT candidates that are similar to incumbent members on less apparent dimensions such as career path, industry experience, and educational background. For a firm in distress, this succession approach would achieve two key short-term objectives, namely to signal to the market that substantial organizational changes are being made, while minimizing the potentially disruptive effect of deeper-level diversification of TMT member characteristics on communication and decision-making effectiveness within the TMT. To obtain a complete picture of these TMT configuration mechanisms, future studies may need to further disentangle multi-dimensional constructs such as demographic and experiential dissimilarity to develop a finer-grained understanding of how TMT diversity emerges at MNEs. 


\section{MANAGERIAL RELEVANCE}

There are practical implications of this study both for MNEs and for aspiring executive candidates. MNEs may consider tapping into the global executive candidate pool in a proactive manner to improve information-processing, gain access to key resources, and signal commitment to international stakeholder communities at critical stages of the internationalization process. An internationally diversified TMT that is capable of handling the challenges and pressures that accompany international expansion is likely to produce a smoother internationalization process with less radical performance fluctuations.

TMT selection practices are affected by a combination of firm- and individual-level factors in the decision to appoint foreign TMT candidates. The TMT appointment process is most likely to shift focus from domestic to international managerial labor markets if the MNE is highly internationalized and performing below average. In the international market for executives, MNEs will particularly seek experienced candidates with a combination of domain-specific and generic managerial skills that can be transferred across contexts. Thus, MNEs are most likely to make foreign TMT appointments under circumstances that raise the need to introduce more managerial diversity and that suppress the perceived costs and risks of taking such steps.

Aspiring top management candidates who aim to get appointed to TMT positions outside their home country are advised to specialize in boundary-spanning functions. The focus of such managers should be on the development of skills and networks that easily transcend organizational and geographical boundaries. International managers with top management ambitions beyond their home country may also need to be more patient about their progress into top positions. 


\section{LIMITATIONS AND FURTHER RESEARCH}

This study is subject to a few limitations that at the same time highlight promising avenues for future research. First, our dependent variable captures only one type of TMT diversity. By employing this model, we overlooked several further TMT diversity characteristics that may be of interest to UE researchers, such as the gender and functional background of new TMT members. The use of multilevel models and methods provides substantial impetus for future research to fundamentally improve our understanding of the antecedents of different TMT configurations and their emergence over time. Furthermore, it is possible that the selection decision can be modeled more accurately by incorporating candidate pool characteristics into the model, provided that TMT candidate pools can be observed and defined in a way that allows for sound and practicable comparison of TMT appointment situations across firms and over time.

Second, our empirical analysis disregards the role of monetary incentives as a potential determinant of cross-border mobility in international executive labor markets. This is essentially a data limitation imposed by the multi-country nature of the study, as consistently reported data on the monetary incentives of executives could not be obtained from the firms included in this study. As executive compensation levels are known to differ somewhat between the countries in our study, it is worth noting that we are unable to account for the different monetary incentives that the executives in our study were faced with. Due to country-specific differences in compensation reporting standards, there is particular impetus for future research to conduct single-country studies that investigate the important role of compensation as an incentive to attract foreign TMT candidates.

Finally, our sample was restricted to MNEs headquartered in seven European countries. While we control for country effects in our empirical model, an extension of this study to a larger number of countries would make it possible to test country-level antecedents of foreign TMT appointments. Due to gradual improvement and alignment of corporate 
reporting standards across the globe, it should become possible to build multi-country databases of MNEs' TMT appointments covering a wide range of countries. This would make it possible to develop a 4-level model with MNEs' country of origin at the highest level of analysis and investigate how country-level factors (e.g., country size, culture, and institutions) are associated with appointments of foreign TMT members. More recent data would additionally provide important insights about whether the same antecedents of foreign TMT appointments persist over time.

\section{CONCLUSION}

This study makes two primary contributions. First, our findings complement recent research on internationalization of TMTs (e.g. Nielsen \& Nielsen, 2011; Schmid \& Dauth, 2014) by showing how foreign TMT appointments are related to three factors that affect the appointment decision: (1) the experiential characteristics of TMT candidates, (2) the type of TMT position to be filled, and (3) the demand for change within the MNE based on its geographical posture and recent performance. Our comprehensive multilevel investigation shows that all three types of factors are associated with the internationalization of TMTs. Overall, the results of this study suggest that MNEs strive to balance the benefits, costs, and risks of appointing foreign TMT candidates. On the one hand, MNEs internationalize their TMTs to overcome liabilities of foreignness and limit performance declines at critical stages of the internationalization process, as internationally diversified TMTs enhance MNEs' information-processing, resource-seeking, and legitimacy-building capabilities. On the other hand, our findings show that MNEs are particularly likely to appoint foreign TMT members under conditions that distinctly emphasize the benefits or suppress the costs and risks of internationalizing the TMT. This suggests that there are strong countervailing forces in MNEs that resist structural and cultural changes in response to changes in strategic posture. These findings may also help to explain why several previous studies have observed that TMT 
diversity emerges gradually and unevenly (Davoine \& Ravasi, 2013; Ruigrok \& Greve, 2008; Staples, 2007), despite widespread recognition that MNEs can benefit from greater managerial diversity.

Second, this paper highlights the potential of multilevel modelling to advance research at the intersection of international business and UE research. We focus on TMT appointments as dependent variables, rather than employing snapshots of TMT configuration as outcomes, and provide an example of how multilevel methods can be employed to investigate the antecedents and mechanisms of TMT composition. This is a method that can be widely employed in response to Hambrick's (2007) call for a better understanding of the underlying factors that determine the selection of TMT members and that drive changes in TMT configuration over time.

\section{ACKNOWLEDGMENTS}

The authors thank Senior Editor Wayne Cascio and two anonymous reviewers for their constructive comments and guidance throughout the review process. The first author and the third author acknowledge financial support from the Swiss National Science Foundation (Research Grant 100018_140455).

\section{NOTES}

${ }^{1}$ Throughout this study, we employ the TMT as a generic term for the highest level of corporate management. This term covers a variety of different labels used by the firms themselves, such as executive committee, executive team, executive board, management board, senior management team, and the like. Similarly, we use the terms top manager and executive interchangeably, both referring to TMT members. 


\section{REFERENCES}

Adams, R. B., Hermalin, B. E., \& Weisbach, M. S. (2010). The role of boards of directors in corporate governance: A conceptual framework and survey. Journal of Economic Literature, 48, 58-107.

Aiken, L. S., \& West, S. G. (1991). Multiple regression: Testing and interpreting interactions. Newbury Park, CA: Sage.

Amburgey, T. L., \& Miner, A. S. (1992). Strategic momentum: The effects of repetitive, positional, and contextual momentum on merger activity. Strategic Management Journal, 13, 335-348.

Athanassiou, N., \& Nigh, D. (1999). The impact of U.S. company internationalization on top management team advice networks: A tacit knowledge perspective. Strategic Management Journal, 20, 83-92.

Athanassiou, N., \& Nigh, D. (2000). Internationalization, tacit knowledge, and the top management teams of MNCs. Journal of International Business Studies, 31, 471-488.

Athanassiou, N., \& Nigh, D. (2002). The impact of the top management team's international business experience on the firm's internationalization: Social networks at work. Management International Review, 42, 157-181.

Athanassiou, N. A., \& Roth, K. (2006). International experience heterogeneity effects on top management team advice networks: A hierarchical analysis. Management International Review, 46, 749-769.

Bartlett, C. A., \& Ghoshal, S. (1989). Managing across borders: The transnational solution. Boston: Harvard Business School Press.

Bartlett, C. A., \& Ghoshal, S. (1992). What is a global manager?. Harvard Business Review, 70(5): 124-132.

Bliese, P. D. (2000). Within-group agreement, non-independence, and reliability: Implications for data aggregation and analysis. In K. J. Klein, \& S. W. Kozlowski (Eds.), Multilevel theory, research, and methods in organizations (pp. 349-381). San Francisco, CA: Jossey-Bass. 
Boone, C., Van Olffen, W., Van Witteloostuijn, A., \& De Brabander, B. (2004). The genesis of top management team diversity: Selective turnover among top management teams in Dutch newspaper publishing, 1970-94. Academy of Management Journal, 47, 633-656.

Bunderson, J. S. (2003). Team member functional background and involvement in management teams: Direct effects and the moderating role of power centralization. Academy of Management Journal, 46, 458-474.

Calori, R., Johnson, G., \& Sarnin, P. (1994). CEOs' cognitive maps and the scope of the organization. Strategic Management Journal, 15, 437-457.

Carpenter, M. A. (2002). The implications of strategy and social context for the relationship between top management team heterogeneity and firm performance. Strategic Management Journal, 23, 275-284.

Carpenter, M. A., \& Fredrickson, J. W. (2001). Top management teams, global strategic posture, and the moderating role of uncertainty. Academy of Management Journal, 44, 533545.

Carpenter, M. A., Geletkanycz, M. A., \& Sanders. W. G. (2004). Upper echelons research revisited: Antecedents, elements and consequences of top management team composition. Journal of Management, 30, 749-778.

Carpenter, M. A., Sanders, W. G., \& Gregersen, H. B. (2001). Bundling human capital with organizational context: The impact of international assignment experience on multinational firm performance and CEO pay. Academy of Management Journal, 44, 493-511.

Chaganti, R., \& Sambharya, R. (1987). Strategic orientation and characteristics of upper management. Strategic Management Journal, 8, 393-401.

Contractor, F. J., Kundu, S. K., \& Hsu, C.-C. (2003). A three-stage theory of international expansion: The link between multinationality and performance in the service sector. Journal of International Business Studies, 34, 5-18.

Dahlin, K. B., Weingart, L. R., \& Hinds, P. J. (2005). Team diversity and information use. Academy of Management Journal, 48, 1107-1123.

Daily, C. M., Certo, S. T., \& Dalton, D. R. (2000). International experience in the executive suite: The path to prosperity?. Strategic Management Journal, 21, 515-523. 
Datta, D. K., \& Guthrie, J. (1994). Executive succession: Organizational antecedents of CEO characteristics. Strategic Management Journal, 15, 569-577.

Datta, D. K., \& Rajagopalan, N. (1998). Industry structure and CEO characteristics: An empirical study of succession events. Strategic Management Journal, 19, 833-852.

Davoine, E., \& Ravasi, C. (2013). The relative stability of national career patterns in European top management careers in the age of globalisation: A comparative study in France / Germany / Great Britain and Switzerland. European Management Journal, 31, 152-163.

Derr, C. B., \& Oddou, G. (1993). Internationalizing managers: Speeding up the process. European Management Journal, 11, 435-442.

Dickmann, M., \& Harris, H. (2005). Developing career capital for global careers: The role of international assignments. Journal of World Business, 40, 399-408.

Echambadi, R., \& Hess, J. D. (2007). Mean-centering does not alleviate collinearity problems in moderated multiple regression models. Marketing Science, 26, 438-445.

Enders, C. K., \& Tofighi, D. (2007). Centering predictor variables in cross-sectional multilevel models: A new look at an old issue. Psychological Methods, 12, 121-138.

Feldman, D. C., \& Thomas, D. C. (1992). Career management issues facing expatriates. Journal of International Business Studies, 23, 271-293.

Fichman, M., \& Cummings, J. N. (2003). Multiple imputation for missing data: Making the most of what you know. Organizational Research Methods, 6, 282-308.

Gaur, A. S., Delios, A., \& Singh, K. (2007). Institutional environments, staffing strategies, and subsidiary performance. Journal of Management, 33, 611-636.

Ghemawat, P. (2011). The cosmopolitan corporation. Harvard Business Review, 89 (May), 82-99.

Gillies, J., \& Dickinson, M. (1999). The governance of transnational firms: Some preliminary hypotheses. Corporate Governance: An International Review, 7, 237-247.

Gong, Y. (2003). Subsidiary staffing in multinational enterprises: Agency, resources, and performance. Academy of Management Journal, 46, 728-739. 
Gong, Y. (2006). The impact of subsidiary top management team national diversity on subsidiary performance: Knowledge and legitimacy perspectives. Management International Review, 46, 771-789.

Graham, J. W. (2009). Missing data analysis: Making it work in the real world. Annual Review of Psychology, 60, 549-576.

Gregersen, H. B., Morrison, A. J., \& Black, J. S. (1998). Developing leaders for the global frontier. Sloan Management Review, 40(1): 21-32.

Greve, P., Nielsen, S., \& Ruigrok, W. (2009). Transcending borders with international top management teams: A study of European financial multinational corporations. European Management Journal, 27, 213-224.

Guo, G., \& Zhao, H. (2000). Multilevel modeling for binary data. Annual Review of Sociology, 26, 441-462.

Gupta, A. K., \& Govindarajan, V. (1984). Business unit strategy, managerial characteristics, and business unit effectiveness at strategy implementation. Academy of Management Journal, $27,25-41$.

Hambrick, D. C. (2007). Upper echelons theory: An update. Academy of Management Review, 32, 334-343.

Hambrick, D. C., Davison, S. C., Snell, S. A., \& Snow, C. C. (1998). When groups consist of different nationalities: Towards a new understanding of the implications. Organization Studies, 19, 181-205.

Hambrick, D. C., Finkelstein, S., \& Mooney, A. C. (2005). Executive job demands: New insights for explaining strategic decisions and leader behaviors. Academy of Management Review, 30, 472-491.

Hambrick, D. C., \& Mason, P. A. (1984). Upper echelons: The organization as a reflection of its top managers. Academy of Management Review, 9, 193-206.

Harris, D., \& Helfat, C. (1997). Specificity of CEO human capital and compensation. Strategic Management Journal, 18, 895-920.

Harzing, A. W. (2001). Who's in charge? An empirical study of executive staffing practices in foreign subsidiaries. Human Resource Management, 40, 139-158. 
Heijltjes, M., Olie, R., \& Glunk, U. (2003). Internationalization of top management teams in Europe. European Management Journal, 21, 89-97.

Helfat, C. E., \& Bailey, E. E. (2005). External succession and disruptive change: Heirsapparent, forced turnover and firm performance. Strategic Organization, 3, 47-83.

Hillman, A. J., Cannella, A. A., \& Paetzold, R. L. (2000). The resource dependence role of corporate directors: Strategic adaptation of board composition in response to environmental change. Journal of Management Studies, 37, 235-255.

Hitt, M. A., Hoskisson, R. E., \& Ireland, R. D. (1994). A mid-range theory of the interactive effects of international and product diversification on innovation and performance. Journal of Management, 20, 297-326.

Hofstede, G. (1991). Cultures and organizations: Software of the mind. London, UK: McGraw-Hill.

Hox, J. J. (1995). Multilevel analysis. Mahwah, NJ: Lawrence Erlbaum Associates.

Joshi, A., Liao, H., Roh, H. (2011). Bridging domains in workplace demography research: A review and reconceptualization. Journal of Management, 37, 521-552.

Kaczmarek, S., \& Ruigrok, W. 2013. In at the deep end of firm internationalization. Management International Review, 53, 513-534.

Kesner, I. F., \& Sebora, T. C. (1994). Executive succession: Past, present and future. Journal of Management, 20, 327-372.

Kirca, A. H., Hult, G. T. M., Deligonul, S., Perryy, M. Z., \& Cavusgil, S. T. (2012). A multilevel examination of the drivers of firm multinationality: A meta-analysis. Journal of Management, 38, 502-530.

Kogut, B., \& Singh, H. (1988). The effect of national culture on the choice of entry mode. Journal of International Business Studies, 19, 411-432.

Kreft, I. (1995). The effects of centering in multilevel analysis: Is the public school the loser or the winner? A new analysis of an old question. Multilevel Modelling Newsletter, 7(3): 5-8.

Lazear, E. P. (1999). Globalisation and the market for team-mates. The Economic Journal, 109, C15-C40. 
LeBreton, J. M., \& Senter, J. L. (2008). Answers to 20 questions about interrater reliability and interrater agreement. Organizational Research Methods, 11, 815-852.

Luo, Y. (2005). How does globalization affect corporate governance and accountability? A perspective from MNEs. Journal of International Management, 11, 19-41.

Magnusson, P., \& Boggs, D. J. (2006). International experience and CEO selection: An empirical study. Journal of International Management, 12, 107-125.

McGraw, K. O., \& Wong, S. P. (1996). Forming inferences about some intraclass correlation coefficients. Psychological Methods, 1, 30-46.

Mellahi, K., \& Collings, D. G. (2010). The barriers to effective global talent management: The example of corporate élites in MNEs. Journal of World Business, 45, 143-149.

Michel, J. G., \& Hambrick, D. C. (1992). Diversification posture and top management team characteristics. Academy of Management Journal, 35, 9-37.

Miller, T., \& Triana, M. C. (2009). Demographic diversity in the boardroom: Mediators of the board diversity-firm performance relationship. Journal of Management Studies, 46, 755-786.

Milliken, F. J., \& Martins, L. L. (1996). Searching for common threads: Understanding the multiple effects of diversity in organizational groups. Academy of Management Review, 21, 402-433.

Murphy, K. J. (1986). Incentives, learning, and compensation: A theoretical and empirical investigation of managerial labor contracts. Rand Journal of Economics, 17, 59-76.

Ng, T. W. H., \& Feldman, D. C. (2008). The relationship of age to ten dimensions of job performance. Journal of Applied Psychology, 93, 392-423.

Nielsen, B. B., \& Nielsen, S. (2011). The role of top management team international orientation in international strategic decision-making: The choice of foreign entry mode. Journal of World Business, 46, 185-193.

Nielsen, B. B., \& Nielsen, S. (2013). Top management team nationality diversity and firm performance: A multilevel study. Strategic Management Journal, 34, 373-382.

Nielsen, S. (2010). Top management team internationalization and firm performance: The mediating role of foreign market entry. Management International Review, 50, 185-206. 
Perlmutter, H. V., \& Heenan, D. A. (1974). How multinational should your top managers be?. Harvard Business Review, 52(6), 121-132.

Petersen, T., \& Saporta, I. (2004). The opportunity structure for discrimination. American Journal of Sociology, 109, 852-901.

Pfeffer, J. (1983). Organizational demography. In B. M. Staw and L. L. Cummings (Eds.), Research in organizational behavior, 5 (pp. 299-357). Greenwich, CT: JAI Press.

Pfeffer, J., \& Salancik, G. (1978). The external control of organizations: A resource dependence perspective. New York: Harper \& Row.

Prahalad, C. K., \& Lieberthal, K. (1998). The end of corporate imperialism. Harvard Business Review, 76(4): 68-79.

R Development Core Team (2008). $R$ : A language and environment for statistical computing.

Rajagopalan, N., \& Datta, D. K. (1996). CEO characteristics: Does industry matter?. Academy of Management Journal, 39, 197-215.

Raudenbush, S. W., \& Bryk, A. S. (2002). Hierarchical linear models. Thousand Oaks, CA: Sage.

Reuber, A. R., \& Fischer, E. (1997). The influence of the management team's international experience on the internationalization behaviors of SMEs. Journal of International Business Studies, 28, 807-825.

Rost, K., Salomo, S., \& Osterloh, M. (2008). CEO appointments and the loss of firm-specific knowledge: Putting integrity back into hiring decisions. Corporate Ownership and Control, 5(3): 86-98.

Roth, P. L. (1994). Missing data: A conceptual review for applied psychologists. Personnel Psychology, 47, 537-560.

Rubin, D. B. (1987). Multiple imputation for nonresponse in surveys. New York: Wiley.

Ruigrok, W., \& Greve, P. (2008). The rise of an international market for executive labour. In L. Oxelheim, \& C. Wihlborg (Eds.), Markets and compensation for executives in Europe (pp. 53-78). Bingley, UK: Emerald.

Salk, J. E., \& Shenkar, O. (2001). Social identities in an international joint venture: An exploratory case study. Organization Science, 12, 161-178. 
Sambharya, R. B. (1996). Foreign experience of top management teams and international diversification strategies of U.S. multinational corporations. Strategic Management Journal, 17, 739-746.

Sanders, W. M., \& Carpenter, M. A. (1998). Internationalization and firm governance: The roles of CEO compensation, top team composition, and board structure. Academy of Management Journal, 41, 158-178.

Schafer, J. L. (1997). Imputation of missing covariates under a multivariate linear mixed model. Technical report, Department of Statistics, Pennsylvania State University.

Schafer, J. L. (2001). Multiple imputation with PAN. In L. M. Collins, \& A. G. Sayer (Eds.), New methods for the analysis of change, 1 (pp. 357-377). Washington, DC: American Psychological Association.

Schafer, J. L., \& Graham, J. W. (2002). Missing data: Our view of the state of the art. Psychological Methods, 7, 147-177.

Schafer, J. L., \& Yucel, R. M. (2002). Computational strategies for multivariate linear mixedeffects models with missing values. Journal of Computational and Graphical Statistics, 11, 437-457.

Schmid, S., \& Dauth, T. (2014). Does internationalization make a difference? Stock market reaction to announcements of international top executive appointments. Journal of World Business, 49, 63-77.

Sinharay, S., Stern, H. S., \& Russell, D. (2001). The use of multiple imputation for the analysis of missing data. Psychological Methods, 6, 317-329.

Snijders, T. A. B. (2005). Fixed and random effects. In B. S. Everitt, \& D. C. Howell (Eds.), Encyclopedia of statistics in behavioral science, 2 (pp. 664-665). Chicester, UK: Wiley.

Staples, C. L. (2007). Board globalisation in the world's largest TNCs 1993-2005. Corporate Governance: An International Review, 15, 311-321.

Staples, C. L. (2008). Cross-border acquisitions and board globalization in the world's largest TNCs, 1995-2005. Sociological Quarterly, 49, 31-51.

Szilagyi, A. D., \& Schweiger, D. M. (1984). Matching managers to strategies: A review and suggested framework. Academy of Management Review, 9, 626-637. 
Thompson, J. D. (1967). Organizations in action. New York: McGraw-Hill.

Tihanyi, L., Ellstrand, A. E., Daily, C. M., \& Dalton, D. R. (2000). Composition of the top management team and firm international diversification. Journal of Management, 26, 11571177.

Triandis, H. C., \& Suh, E. M. (2002). Cultural influences on personality. Annual Review of Psychology, 53, 133-160.

Tsui, A. S., Egan, T. D., \& O’Reilly III, C. A. (1992). Being different: Relational demography and organizational attachment. Administrative Science Quarterly, 37, 549-579.

Tushman, M. L., \& Scanlan, T. J. (1981). Characteristics and external orientations of boundary spanning individuals. Academy of Management Journal, 24, 83-98.

Tushman, M. L., \& Scanlan, T. J. (1981a). Boundary spanning individuals: Their role in information transfer and their antecedents. Academy of Management Journal, 24, 289-305.

Van Veen, K., \& Marsman, I. (2008). How international are executive boards of European MNCs? Nationality diversity in 15 European countries. European Management Journal, 26, 188-198.

Vermeulen, F., \& Barkema, H. (2002). Pace, rhythm, and scope: Process dependence in building a profitable multinational corporation. Strategic Management Journal, 23, 637-653.

Wagner, W. G., Pfeffer, J., \& O’Reilly III, C. A. (1984). Organizational demography and turnover in top-management groups. Administrative Science Quarterly, 29, 74-92.

Williams, K. Y., \& O’Reilly III, C. A. (1998). Demography and diversity in organizations: A review of 40 years of research. In B. M. Staw and L. L. Cummings (Eds.), Research in organizational behavior, 20 (pp. 77-140). Greenwich, CT: JAI Press.

Zaheer, S. (1995). Overcoming the liability of foreignness. Academy of Management Journal, $38,341-363$.

Zajac. E. J. (1990). CEO selection, succession, compensation and firm performance: A theoretical integration and empirical analysis. Strategic Management Journal, 11, 217-230. 


\section{FIGURES}

Figure 1: Hypothesized Determinants of Foreign Executive Appointments

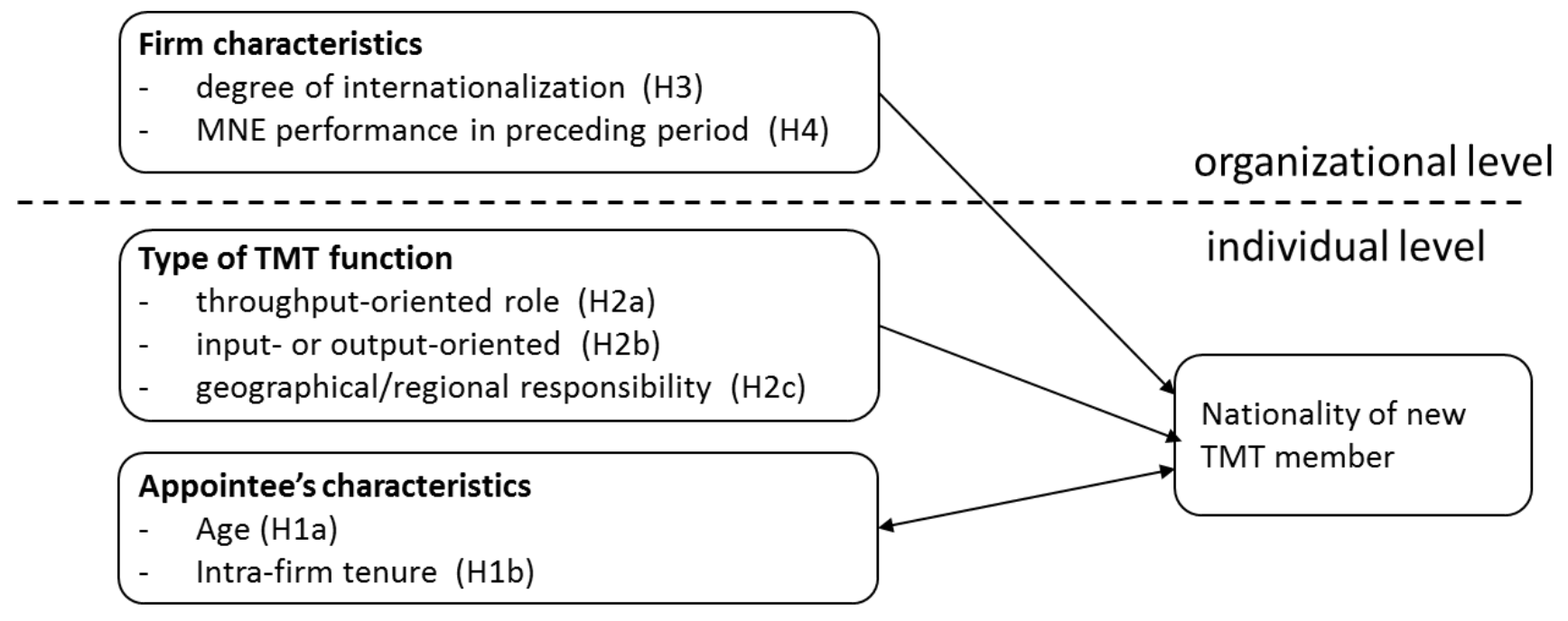




\section{TABLES}

Table 1: Means, Standard Deviations, and Correlations ${ }^{a}$

\begin{tabular}{|c|c|c|c|c|c|c|c|c|c|c|c|c|c|c|c|c|}
\hline & mean & sd & 1 & 2 & 3 & 4 & 5 & 6 & 7 & 8 & 9 & 10 & 11 & 12 & 13 & 14 \\
\hline 1. $\quad$ Foreigner $($ yes $=1)$ & 0.29 & 0.45 & - & $.15 * * *$ & $-.07 * *$ & .03 & .03 & $-.15 * * *$ & .05 & $.28 * * *$ & & & & & & \\
\hline 2. Age at entry & 46.9 & 6.27 & $.17 * * *$ & - & $-.11 * * *$ & $.25 * * *$ & $.09 * * *$ & $-.13 * * *$ & .01 & $.08^{*}$ & & & & & & \\
\hline 3. Gender $($ female $=1)$ & 0.08 & 0.26 & -.07 & $-.09 *$ & - & $-.06^{*}$ & -.04 & $.18 * * *$ & $-.11 * * *$ & $-.08 * *$ & & & & & & \\
\hline 4. Organizational tenure & 8.60 & 9.29 & .04 & $.28 * * *$ & -.03 & - & $-.07 *$ & $-.16^{* * *}$ & $.19 * * *$ & $.11 * * *$ & & & & & & \\
\hline 5. General Management & 0.25 & 0.43 & .03 & .06 & -.03 & $-.07 *$ & - & $-.28 * * *$ & $-.13 * * *$ & $.12 * * *$ & & & & & & \\
\hline 6. $\quad$ Throughput function & 0.27 & 0.44 & $-.10 * *$ & $-.13 * *$ & $.13 * * *$ & $-.14 * * *$ & $-.27 * * *$ & - & $-.60 * * *$ & $-.21 * * *$ & & & & & & \\
\hline 7. Input/Output function & 0.53 & 0.50 & .02 & -.03 & $-.08 *$ & $.15 * * *$ & $-.20 * * *$ & $-.57 * * *$ & - & $-.12 * * *$ & & & & & & \\
\hline 8. $\quad$ Regional responsibilities & 0.12 & 0.32 & $.23 * * *$ & $.10^{* *}$ & -.07 & $.10^{* *}$ & $.16^{* * *}$ & $-.19 * * *$ & $-.09 *$ & - & & & & & & \\
\hline 9. $\quad$ Size of TMT & 7.28 & 3.10 & $.12^{* *}$ & -.02 & $.10^{*}$ & $.17 * * *$ & $-.11 * *$ & $-.15 * * *$ & $.26 * * *$ & $.15^{* * *}$ & - & & & & & \\
\hline 10. Mean age TMT & 50.12 & 3.73 & -.01 & $.24 * * *$ & -.04 & $.26 * * *$ & .00 & -.02 & -.02 & -.05 & -.05 & - & & & & \\
\hline 11. Percentage foreigners & 0.22 & 0.26 & $.46^{* * *}$ & .06 & -.07 & .04 & $-.11 * *$ & .04 & .00 & $.09 *$ & $.19 * * *$ & .07 & - & & & \\
\hline 12. Mean TMT tenure & 5.14 & 3.13 & $-.15 * * *$ & -.02 & -.02 & $.11^{* *}$ & .01 & -.02 & -.01 & -.06 & $-.14 * * *$ & $.41 * * *$ & $-.15 * * *$ & - & & \\
\hline 13. Annual sales & 6016.4 & 14836.7 & $.09 *$ & $.09 *$ & .03 & $.26 * * *$ & -.04 & -.02 & .05 & .02 & $.08 *$ & $.17 * * *$ & $.20 * * *$ & -.01 & - & \\
\hline 14. $\mathrm{ROA} \mathrm{t}-1$ & 5.53 & 10.09 & -.06 & .05 & .03 & $.08^{*}$ & -.02 & -.02 & .06 & .00 & .00 & $.12 * *$ & -.01 & $.11 * *$ & .06 & - \\
\hline 15. Degree of international. & 0.61 & 0.36 & $.32 * * *$ & $.08 *$ & -.01 & $.15 * * *$ & -.05 & -.06 & .02 & $.15^{* * *}$ & $.22 * * *$ & $.17 * * *$ & $.49 * * *$ & .00 & $.16 * * *$ & .06 \\
\hline
\end{tabular}


Table 2: Results from Multilevel Models

\begin{tabular}{|c|c|c|c|}
\hline & \multicolumn{3}{|c|}{ Foreign/Domestic Executive (logit model) } \\
\hline & $\begin{array}{c}\text { Model 1 } \\
\text { (Base Model) }\end{array}$ & $\begin{array}{c}\text { Model } 2 \\
\text { (Level } 1 \text { predictors) }\end{array}$ & $\begin{array}{c}\text { Model 3 } \\
\text { (Full Model) }\end{array}$ \\
\hline \multicolumn{4}{|l|}{ Level 1} \\
\hline Gender (CGM) & $\begin{array}{c}-0.688 * * \\
(0.246) \\
\end{array}$ & $\begin{array}{l}-0.240 \\
(0.240) \\
\end{array}$ & $\begin{array}{l}-0.222 \\
(0.241) \\
\end{array}$ \\
\hline Age at entry (CGM) & - & $\begin{array}{c}0.063 * * * \\
(0.011)\end{array}$ & $\begin{array}{c}0.063 * * * \\
(0.012)\end{array}$ \\
\hline $\begin{array}{l}\text { Organizational tenure (prior to } \\
\text { entering TMT) (CGM) }\end{array}$ & - & $\begin{array}{l}-0.016 \\
(0.008) \\
\end{array}$ & $\begin{array}{l}-0.016 \\
(0.009) \\
\end{array}$ \\
\hline General Management (CWC) & - & $\begin{array}{l}-0.080 \\
(0.216)\end{array}$ & $\begin{array}{l}-0.078 \\
(0.217) \\
\end{array}$ \\
\hline Throughput function (CWC) & - & $\begin{array}{l}-0.494 \\
(0.298)\end{array}$ & $\begin{array}{l}-0.500 \\
(0.299) \\
\end{array}$ \\
\hline Input/Output function (CWC) & - & $\begin{array}{l}0.646^{*} \\
(0.263) \\
\end{array}$ & $\begin{array}{l}0.659^{*} \\
(0.266)\end{array}$ \\
\hline Regional responsibility (CWC) & - & $\begin{array}{c}2.432 * * * \\
(0.399)\end{array}$ & $\begin{array}{l}2.434 * * * \\
(0.394)\end{array}$ \\
\hline \multicolumn{4}{|l|}{ Level 2} \\
\hline Year (CGM) & $\begin{array}{l}-0.004 \\
(0.064)\end{array}$ & $\begin{array}{c}0.003 \\
(0.067)\end{array}$ & $\begin{array}{l}-0.022 \\
(0.068)\end{array}$ \\
\hline TMT size (CGM) & $\begin{array}{c}0.041 \\
(0.023) \\
\end{array}$ & $\begin{array}{c}0.046 \\
(0.024) \\
\end{array}$ & $\begin{array}{c}0.041 \\
(0.024) \\
\end{array}$ \\
\hline Mean age (CGM) & $\begin{array}{l}-0.028^{*} \\
(0.021) \\
\end{array}$ & $\begin{array}{l}-0.048^{*} \\
(0.021) \\
\end{array}$ & $\begin{array}{l}-0.048^{*} \\
(0.023) \\
\end{array}$ \\
\hline $\begin{array}{l}\text { Percentage of foreign members t-1 } \\
(\mathrm{CGM})\end{array}$ & $\begin{array}{c}2.572 * * * \\
(0.301)\end{array}$ & $\begin{array}{c}2.790 * * * \\
(0.311)\end{array}$ & $\begin{array}{c}2.040 * * * \\
(0.373)\end{array}$ \\
\hline Mean TMT tenure (CGM) & $\begin{array}{l}-0.031 \\
(0.030)\end{array}$ & $\begin{array}{l}-0.016 \\
(0.030) \\
\end{array}$ & $\begin{array}{l}-0.022 \\
(0.031) \\
\end{array}$ \\
\hline Sales $(\mathrm{CGM})^{\mathrm{a}}$ & $\begin{array}{c}0.004 \\
(0.005)\end{array}$ & $\begin{array}{l}0.005 \\
(0.005)\end{array}$ & $\begin{array}{c}0.002 \\
(0.005)\end{array}$ \\
\hline ROA t-1 (CGM) & - & - & $\begin{aligned}-0.018 * \\
(0.008) \\
\end{aligned}$ \\
\hline \multicolumn{4}{|l|}{ Level 3} \\
\hline Intercept & $\begin{array}{c}-1.205^{* * * *} \\
(0.073)\end{array}$ & $\begin{array}{c}-1.264 * * * \\
(0.076)\end{array}$ & $\begin{array}{c}-1.313 * * * \\
(0.082)\end{array}$ \\
\hline
\end{tabular}




\begin{tabular}{|c|c|c|c|}
\hline Country dummies (CGM) & Yes & Yes & Yes \\
\hline Industry dummies (CGM) & Yes & Yes & Yes \\
\hline $\begin{array}{l}\text { Degree of internationalization } \\
\text { (CGM) }\end{array}$ & - & - & $\begin{array}{c}1.560 * * * \\
(0.373)\end{array}$ \\
\hline df (level 1, level 2, level 3) & $(1407,684,330)$ & $(1403,684,330)$ & $(1401,683,329)$ \\
\hline \multicolumn{4}{|c|}{$\begin{array}{l}\text { Notes. Reported are average gamma coefficients with robust standard errors based on five data sets } \\
\text { with imputed missing values (see text for details); standard errors in parentheses; in the logit } \\
\text { model, parameters are from the population model; CGM = centered at the grand mean; CWC = } \\
\text { centered within clusters; } \mathrm{df}=\text { degrees of freedom. } \\
\text { a shown are values multiplied by } 10^{3} \\
* \mathrm{p}<.05 ; * * \mathrm{p}<.01 ; * * * \mathrm{p}<0.001\end{array}$} \\
\hline
\end{tabular}

